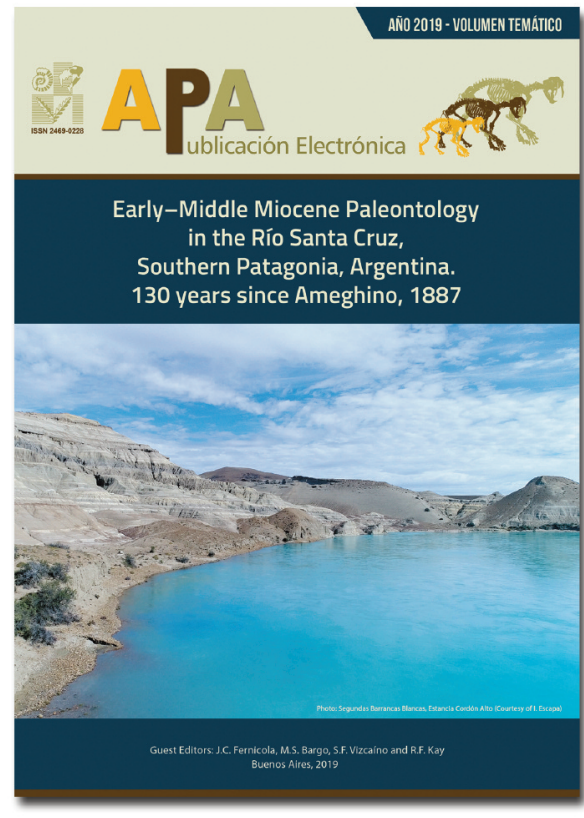

\title{
CINGULATES (MAMMALIA, XENARTHRA) OF THE SANTA CRUZ FORMATION (EARLY-MIDDLE MIOCENE) FROM THE RÍO SANTA CRUZ, ARGENTINE PATAGONIA
}

JUAN C. FERNICOLA ${ }^{1,2,3}$

SERGIO F. VIZCAIINO3,4

\begin{abstract}
1Sección Paleontología de Vertebrados, Museo Argentino de Ciencias Naturales "Bernardino Rivadavia". Av. Ángel Gallardo 470, 1405DJR Ciudad Autónoma de Buenos Aires, Argentina.

2Universidad Nacional de Luján, Departamento de Ciencias Básicas. Ruta 5 y Av. Constitución, 6700 Luján, Buenos Aires, Argentina.

${ }^{3}$ Comisión Nacional de Investigaciones Científicas y Técnicas (CONICET).

${ }^{4}$ División Paleontología Vertebrados, Museo de La Plata, Unidades de Investigación Anexo Museo, Facultad de Ciencias Naturales y Museo. Av. 60 y 122, B1904 La Plata, Argentina.
\end{abstract}

Recibido: 1 de abril 2019 - Aceptado: 14 de octubre 2019

Para citar este artículo: Juan C. Fernicola, and Sergio F. Vizcaíno (2019). Cingulates (Mammalia, Xenarthra) of the Santa Cruz Formation (Early-Middle Miocene) from the Río Santa Cruz, Argentine Patagonia. Publicación Electrónica de la Asociación Paleontológica Argentina 19 (2): 85-101.

Link a este artículo: http://dx.doi.org/10.5710/PEAPA.14.10.2019.291

DESPLAZARSE HACIA ABAJO PARA ACCEDER AL ARTÍCULO

Asociación Paleontológica Argentina Maipú $6451^{\circ}$ piso, C1006ACG, Buenos Aires República Argentina Tel/Fax (54-11) 4326-7563

Otros artículos en Publicación Electrónica de la APA 19(2): Web: www.apaleontologica.org.ar

\section{L.M. Pérez et al.}

\section{DIPLODONCF. COLHUAPIENSIS}

(BIVALVIA-HYRIIDAE) IN SANTA CRUZ FORMATION (EARLY-MIDDLE MIOCENE), AT THE RÍO SANTA CRUZ, PATAGONIA, ARGENTINA. STRATIGRAPHIC AND PALEOENVIRONMENTAL CONSIDERATIONS

\section{J. Diederle, J. Noriega}

NEW RECORDS OF BIRDS IN THE SANTA CRUZ FORMATION AT RÍO SANTA CRUZ, ARGENTINA, PATAGONIA

\section{Chornogubsky}

THE METATHERIA FROM THE RÍO SANTA CRUZ (SANTA CRUZ FORMATION, EARLY-MIDDLE MIOCENE, ARGENTINA): HISTORY AND NEW FINDINGS 


\title{
CINGULATES (MAMMALIA, XENARTHRA) OF THE SANTA CRUZ FORMATION (EARLY-MIDDLE MIOCENE) FROM THE RÍO SANTA CRUZ, ARGENTINE PATAGONIA
}

\author{
JUAN C. FERNICOLA'1,2,3, AND SERGIO F. VIZCAIINO3,4
}

'Sección Paleontología de Vertebrados, Museo Argentino de Ciencias Naturales "Bernardino Rivadavia". Av. Ángel Gallardo 470, 1405DJR Ciudad Autónoma de Buenos Aires, Argentina.jctano@yahoo.com

universidad Nacional de Luján, Departamento de Ciencias Básicas. Ruta 5 y Av. Constitución, 6700 Luján, Buenos Aires, Argentina. ${ }^{3}$ Comisión Nacional de Investigaciones Científicas y Técnicas (CONICET).

4División Paleontología Vertebrados, Museo de La Plata, Unidades de Investigación Anexo Museo, Facultad de Ciencias Naturales y Museo. Av. 60 y 122 , B1904 La Plata, Argentina.vizcaino@fcnym.unlp.edu.ar

\begin{abstract}
In 1887 Carlos Ameghino carried out the earliest extensive exploration of the fossiliferous localities along the Río Santa Cruz (Patagonia). His brother Florentino erected more than 100 vertebrate species based on the remains that Carlos recovered. The faunal assemblage eventually came to be recognized as the Santacrucian South American Land Mammal Age (Early-Middle Miocene). Over the past several years, an interdisciplinary group from the Museo de La Plata, Museo Argentino de Ciencias Naturales "Bernardino Rivadavia" (Argentina), and Duke University (USA) revisited the Río Santa Cruz localities, including Barrancas Blancas, Segundas Barrancas Blancas, and Yaten Huageno. This contribution presents a taxonomic list of cingulates based on the abundant material recovered during these expeditions. In Barrancas Blancas, we recorded the armadillos Peltephilus pumilus Ameghino, Stenotatus patagonicus Ameghino, Proeutatus oenophorus Ameghino, Prozaedyus proximus Ameghino, and Stegotherium tessellatum Ameghino, and the glyptodonts Cochlops muricatus Ameghino and Eucinepeltus sp. Ameghino. We did not record St. tessellatum in Segundas Barrancas Blancas and St. tessellatum, P. pumilus and Eucinepeltus sp. in Yaten Huageno. The comparative analysis between the faunal composition of the Santa Cruz Formation in the Río Santa Cruz and other areas to the west and the east reveals minor differences that, preliminarily, suggest environmental differences between the analyzed regions.
\end{abstract}

Key words. Santacrucian. Armadillos. Glyptodonts. Taxonomy. Carlos and Florentino Ameghino.

Resumen. CINGULADOS (MAMMALIA, XENARTHRA) DE LA FORMACIÓN SANTA CRUZ (MIOCENO TEMPRANO-MEDIO) DEL RÍO SANTA CRUZ, PATAGONIA ARGENTINA. En 1887 Carlos Ameghino llevó a cabo la expedición más importante que prospectó las localidades ubicadas a lo largo del Río Santa Cruz. Los fósiles recolectados le permitieron a su hermano Florentino erigir más de 100 especies de vertebrados. Este conjunto faunístico sería reconocido mundialmente como la Edad Mamífero Santacrucense (Mioceno Temprano-Medio). En los últimos años un grupo interdisciplinario del Museo de La Plata, el Museo Argentino de Ciencias Naturales "Bernardino Rivadavia" (Argentina) y la Duke University (USA) realizó expediciones a las localidades del Río Santa Cruz incluyendo Barrancas Blancas, Segundas Barrancas Blancas y Yaten Huageno. En esta contribución presentamos una lista taxonómica de los cingulados sustentada en la gran cantidad de especímenes recolectados en las expediciones arriba mencionadas. En Barrancas Blancas registramos los armadillos Peltephilus pumilus Ameghino, Stenotatus patagonicus Ameghino, Proeutatus oenophorus Ameghino, Prozaedyus proximus Ameghino y Stegotherium tessellatum Ameghino y los glyptodontes Cochlops muricatus Ameghino y Eucinepeltus sp. Ameghino. En Segundas Barrancas Blancas no registramos St. tessellatum y en Yaten Huageno no se registraron St. tessellatum, P. pumilus y Eucinepeltus sp. El análisis comparativo entre esta composición faunística y las registradas para la Formación Santa Cruz en otras áreas ubicadas al oeste y al este del Río Santa Cruz, permite reconocer pequeñas diferencias faunísticas que, en forma preliminar, sugieren diferencias ambientales entre las regiones evaluadas.

Palabras clave. Santacrucense. Armadillos. Gliptodontes. Taxonomía. Carlos y Florentino Ameghino.

CINGULATES (armadillos, including the specialized glyptodonts) are grouped with anteaters and sloths as Xenarthra, a group of mammals with only a modest current representation in the Americas, but that was much more diverse during the
Cenozoic. Their most conspicuous feature is the presence of armor composed of osteoderms covered with epidermal scales protecting the head, body, and tail. Extant cingulates include 10 genera of armadillos (Wetzel, 1985; Aguiar and 
Fonseca, 2008; Castro et al., 2015), whereas more than 65 extinct genera, including specialized armadillos such as peltephilids, pampatheres, and glyptodonts, have been described (Mones, 1986; McKenna and Bell, 1997). Except for the pampatheres, they were common during the EarlyMiddle Miocene, particularly as part of the Santacrucian South American Land Mammal Age (SALMA) faunas of the Santa Cruz Formation (SCF; Burdigalian-early Langhian).

The SCF is a continental sedimentary succession distributed over a large area of southern Patagonia, within the Austral-Magallanes Basin (Fosdick et al., 2013; Cuitiño et al., 2016; Ghiglione et al., 2016; Parras and Cuitiño, 2018). The unit is composed of mudstones, tuffaceous sandstones, and tuffs deposited in fluvial environments under the influence of intense explosive pyroclastic input (Matheos and Raigemborn, 2012; Raigemborn et al., 2015; Cuitiño et al., 2016). In the Province of Santa Cruz, it is exposed in the northwest area (Cuitiño et al., 2019a), in the central region along the Ríos Santa Cruz (Fernicola et al., 2014; Cuitiño et al., 2016) and Chalía (= Sehuén; Vizcaíno et al., 2018), and in the southeastern area along the Atlantic coast (Vizcaíno et al., 2012a,b). This unit contains the richest pre-Pleistocene assemblage of mammalian skulls and articulated skeletons on the continent (Kay et al., 2008; Vizcaíno et al., 2010, 2012a) and was seminal for the construction of the South American Land Mammal Age scheme in Patagonia (Pascual et al., 1965; Vizcaíno et al., 2012a). The Río Santa Cruz (RSC) extends from Lago Argentino and flows from west to east through a broad and deeply incised valley stretching $230 \mathrm{~km}$ from west to east. Along the RSC two Miocene sedimentary units of the Austral-Magallanes Basin can be recognized: (1) the shallow marine to deltaic Early Miocene Monte León Formation (Sacomani and Panza, 2011; Parras and Cuitiño, 2018), and (2) the terrestrial Early-Middle Miocene SCF (Tauber et al., 2008; Sacomani and Panza, 2011; Cobos et al., 2014; Fernicola et al., 2014; Cuitiño et al., 2016). The outcrops of the SCF along the southern margin of the RSC were described by Cuitiño et al. (2016, 2019b) and three fossil localities were recognized by Fernicola et al. (2014, 2019); from east to west they are: Barrancas Blancas (BB), Segundas Barrancas Blancas (SBB), and Yaten Huageno (YH; Fig. 1). Based on radiometric ages, the entire SCF represents a span of $\sim 18.0$ to $\sim 15.6 \mathrm{Ma}$; the localities along the Atlantic coast range between $\sim 18.0$ to $\sim 16.0 \mathrm{Ma}$ (Fleagle et al., 2012; Perkins et al., 2012; Trayler et al., 2019), and between $\sim 18.20$ to $15.6 \mathrm{Ma}$ in the Río Bote and Río Santa Cruz localities (Cuitiño et al., 2016).

Moreno (1882) provided the first mention of cingulates from the SFC in a brief list of terrestrial fossil mammals from the RSC. Among them, he included the glyptodont Hoplophorus australis Moreno, 1882, which is currently recognized as a nomen nudum (Ameghino, 1889). Florentino Ameghino (1887) studied the remains (osteoderms) noted by Moreno together with an assemblage of exo- and en-

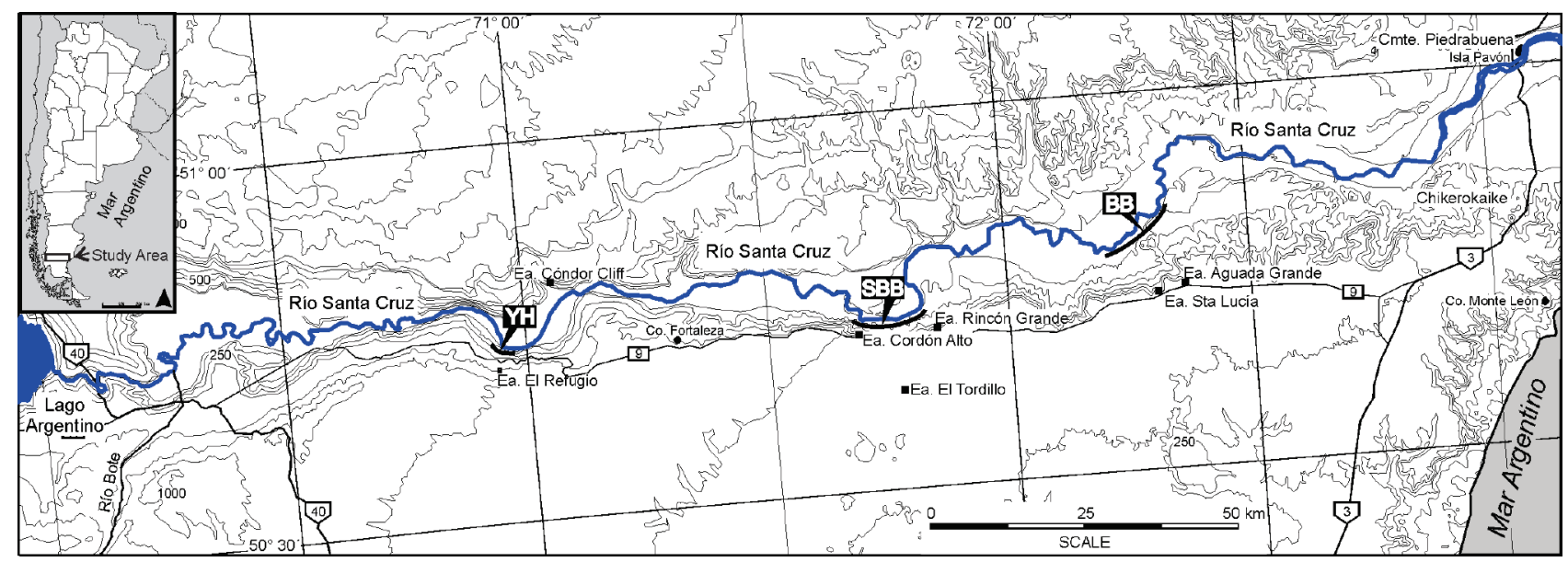

Figure 1. Map of the Río Santa Cruz with the prospected localities and estancias mentioned in the text. BB, Barrancas Blancas; SBB, Segundas Barrancas Blancas; YH, Yaten Huageno; Ea., Estancia. Modified from Fernicola et al. (2014). 
doskeletal remains collected from the same outcrops by Carlos Ameghino, and provided the first formal descriptions of Santacrucian cingulates. He named 11 species of armadillos, currently assigned to Peltephilus Ameghino, 1887, Stegotherium Ameghino, 1887, Prozaedyus Ameghino, 1891a, Proeutatus Ameghino, 1891a, and Stenotatus Ameghino, 1891a, and two species of the glyptodont Propalaehoplophorus Ameghino, 1887. Later, Ameghino (1889, 1891a, 1894, 1898, 1900-02) erected other genera of Santacrucian cingulates, three armadillos and four glyptodonts, based on specimens collected from other regions. Moreno and Mercerat (1891) and Mercerat (1890, 1891) named different taxa that Ameghino (1891b, 1894) did not accept. Lydekker (1894) synonymized most of the Santacrucian taxa proposed by Ameghino and Mercerat. In an extensive work, the first part of which was published in 1895 and the second posthumously, Ameghino (1895, 1920) rejected, sometimes without providing evidence, nearly all the synonymies proposed by Lydekker (1894). Scott (1903) validated most of the taxa originally erected by Florentino Ameghino. Subsequently published taxonomic revisions have dealt with only a very few taxa (see below).

Recent exhaustive fieldwork (Fernicola et al., 2019) has provided new material of cingulates from Santacrucian localities along the RSC, allowing, after over a century, new views on the taxonomic richness of this group of mammals. These new remains were recovered by collaborative expeditions involving the Museo de La Plata (MLP) and Museo Argentino de Ciencias Naturales "Bernardino Rivadavia" (MACN; Argentina), and Duke University (USA). This contribution reviews the taxonomic richness of Santacrucian cingulates collected by the MLP-MACN-Duke expeditions along the RSC and evaluates it with regard to that recorded from other Santacrucian localities.

\section{SANTACRUCIAN CINGULATES}

The taxonomy of the Santacrucian Cingulata proposed during the late $19^{\text {th }}$ century was highly controversial until Scott's (1903) revisions. In addition to the thorough descriptions and extensive taxonomic breadth, quality, and abundance of figured specimens, Scott's contribution gained wide acceptance also because he studied all of the most important collections of Santacrucian cingulates then available. His work described, for the first time, the specimens collected by John B. Hatcher and Barnum Brown between the years 1886 and 1890, housed in Princeton University and the American Museum of Natural History, and compared them with the type and reference specimens in the MLP and Ameghino's personal collection (the latter currently housed in the MACN) (Vizcaíno et al., 2012a).

A century would pass before González Ruiz (2010) performed the next, albeit unpublished, comprehensive taxonomic revision of the Santacrucian cingulates. Other revisions were limited to peltephilids (Bordas, 1936, 1938) and Stegotherium (Fernicola and Vizcaíno, 2008; González Ruiz and Scillato-Yané, 2008, 2009).

The current taxonomic scheme, according to the published literature (Scott, 1903; Bordas, 1936, 1938; Fernicola and Vizcaíno, 2008; González Ruiz and Scillato-Yané, 2008, 2009; Vizcaíno et al., 2012c) and followed here, of Santacrucian cingulates recognizes six genera of armadillos: Peltephilus, Proeutatus, Prozaedyus, Stegotherium, Stenotatus, and Vetelia Ameghino, 1891c. The species level systematics, which has not been considered since Scott (1903), is less certain, and we do not agree with several of this author's taxonomic actions. These species are considered in the Systematic Paleontology section. Three other genera have been erected based on remains from Santacrucian deposits, Anatiosodon Ameghino, 1891a, Eodasypus Ameghino, 1894, and Pareutatus Scott, 1903. The status of these genera is controversial due largely and variably to the limited material on which the taxon was erected, poor original descriptions, unsupported by proper illustrations, and the type specimen is either of ambiguous identity or lost. Anatiosodon is represented by Anantiosodon rarus Ameghino, 1891a. Scott (1903) assigned this species, with reservation, to Peltephilus, but Bordas (1938) did not accept this taxonomic decision and retained the species in Anatiosodon. Vizcaíno and Fariña (1997) suggested that the type specimen, a mandibular fragment, may represent a juvenile individual, and Vizcaíno et al. (2012c) agreed (although without providing supporting evidence) with Scott's (1903) assignment to Peltephilus. The possible juvenile condition of the specimen prevents considering its status beyond Peltephilus sp. The second genus, Eodasypus, was 
considered by Scott (1903) and Scillato-Yané (1980) as incertae sedis. Further, as the type specimens of the two species assigned to Eodasypus, E. nanus (Ameghino, 1891b) and E. limus (Ameghino, 1891b), cannot be located in the Ameghino collection and they are poorly described (Ameghino 1891b), this genus will not be considered in this study. Finally, the specimen used by Scott (1903) to support the taxonomic identity of Pareutatus distans (Ameghino, 1887) includes osteoderms and a skull and mandible (MACN-A 7972-7974). A perfunctory examination of the cranial features provided by Scott (1903) might allow its recognition as a different genus from the remaining Santacrucian taxa, but a more thorough analysis reveals many similarities with the skull of Stenotatus and the osteoderms purportedly associated with the skull are very similar to those of Proeutatus. Although Ameghino's catalog at the MACN notes that all the remains cataloged as MACN-A 7972-7974 belong to the same individual, their association according to Scott (1903, p. 68) is doubtful. Given the ambiguous status of Pareutatus distans, and doubts about the association of the fossil remains it is not considered in this study.

Scott (1903) recognized five glyptodont genera, Propalaehoplophorus, Eucinepeltus Ameghino, 1891a, Cochlops Ameghino, 1889, Asterostemma Ameghino, 1889 and Metopotoxus Ameghino, 1898. The last two genera were based on small fragments of osteoderms that do not allow identification beyond Propalaehoplophoridae (sensu Fernicola, 2008). Again, at the species level we disagree with some taxa proposed by Scott (1903), and treat them in the Systematic Paleontology.

\section{MATERIALS AND METHODS}

The approximately 370 specimens of cingulates studied here were collected between 2013-2014 by the MLPMACN-Duke Univeristy expeditions (Fernicola et al., 2019), and belong to the Museo Regional Provincial "Padre M. Jesús Molina" of Río Gallegos (Province of Santa Cruz, Argentina) (Appendix 1). These specimens were identified through comparison with the type specimens and with more complete remains of specimens housed in the institutions mentioned below. Quotation marks indicate that there is a lack of consensus on the monophyly of a suprageneric group.
Osteoderms were measured with manual calipers; the descriptive terminology follows Fernicola and Vizcaíno (2008), Krmpotic et al. (2009), Ciancio et al. (2013), and Francia and Ciancio (2013) (Fig. 2).

The geographic references for the localities reported for the SCF are grouped as follows: 1) eastern area, including the Atlantic coast, 2) central area, including RSC and Río Chalía (= Sehuen), 3) western area, including the Lago Argentino and Lago Posadas regions (see Fernicola et al., 2019, fig. 1). The localities along the RSC are BB ( 17.45 to $\sim 16.49 \mathrm{Ma} ; \mathrm{S} 50^{\circ} 9^{\prime} 38.31^{\prime \prime} \mathrm{W} 69^{\circ} 40^{\prime} 23.40^{\prime \prime}$ to S $50^{\circ} 12^{\prime}$ $31.70^{\prime \prime}$ W $\left.69^{\circ} 43^{\prime} 10.66^{\prime \prime}\right)$, SBB ( 16.43 to $15.63 \mathrm{Ma}$; S 50 $16^{\prime} 12.48^{\prime \prime} \mathrm{W} 70^{\circ} 22^{\prime} 23.21^{\prime \prime}$ to $50^{\circ} 16^{\prime} 51.90^{\prime \prime} \mathrm{W} 70^{\circ} 17^{\prime}$ 54.76") and YH ( 17.22 to $16.67 \mathrm{Ma}$; S 50 ${ }^{\circ} 15^{\prime} 17.48^{\prime \prime} \mathrm{W}$ $71^{\circ} 4^{\prime} 9.56^{\prime \prime}$ to $550^{\circ} 15^{\prime} 17.48^{\prime \prime} \mathrm{W} 71^{\circ} 4^{\prime} 9.56^{\prime \prime}$ ) (Fernicola et al., 2014, 2019; Cuitiño et al., 2016, 2019b).

The comparative study on the taxonomic richness of the RSC cingulates includes three levels of analysis. The first considers the taxonomic richness referred to the RSC by Ameghino $(1887,1889)$ with that obtained based on the new remains. The second considers the richness among the three localities BB, SBB, and $\mathrm{YH}$, based only on the new remains, as previous works that provided faunal lists from the RSC did not discriminate among the three localities (e.g., Ameghino, 1887). The third level of analysis includes com-

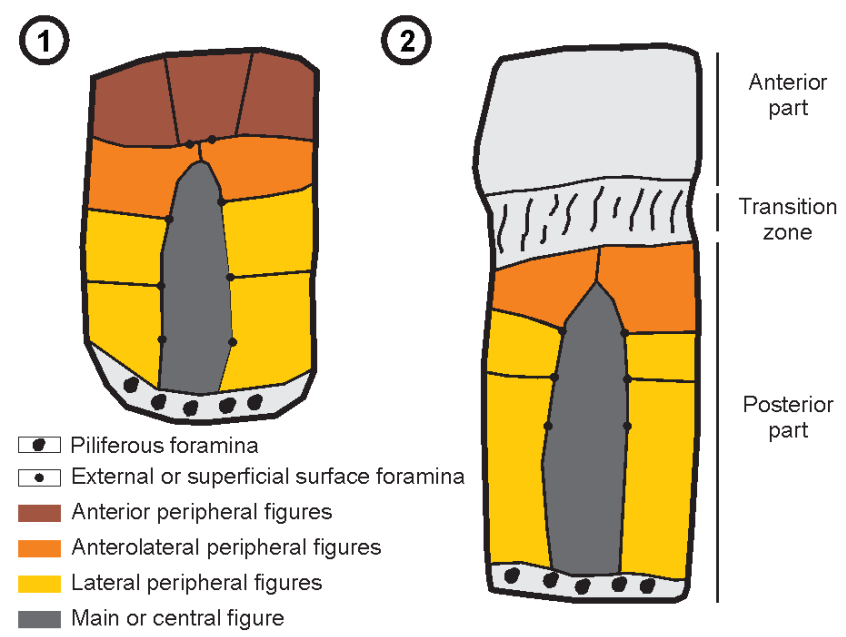

Figure 2. Terminology of the osteoderm features mentioned in the text. 1, fixed osteoderm; 2 , moveable osteoderm. 
parison of the taxonomic richness of the RSC with that recognized for the remaining SCF locations in the eastern, central and western regions. This last level includes information related to the geographical distribution of the Santacrucian cingulates as compiled from Ameghino (1887, 1889, 1891a-d, 1894, 1900-02, 1906), Scott (1903), Tauber (1999), González Ruiz and Scillato-Yané (2008, 2009), and Vizcaíno et al. (2012c). Comparison of the taxonomic richness in each level of analysis is based on the presence or absence of each taxon listed in each locality.

Institutional abbreviations. MPM-PV, Museo Regional Provincial "Padre M. Jesús Molina", Río Gallegos, Argentina. MACN-A, Museo Argentino de Ciencias Naturales "Bernardino Rivadavia", Colección Nacional Ameghino, Buenos Aires, Argentina. MACN-Ma, Museo Argentino de Ciencias Naturales "Bernardino Rivadavia", Colección Nacional de Mastozoología, Buenos Aires, Argentina. YPM-VPPU, Yale Peabody Museum, Vertebrate Paleontology, New Haven, USA.

\section{SYSTEMATIC PALEONTOLOGY}

Order XenaRTHRa Cope, 1889

Suborder Cingulata Illiger, 1811

Family Peltephilidae Ameghino, 1894

Genus Peltephilus Ameghino, 1887

Type species. Peltephilus strepens Ameghino, 1887. Santa Cruz Formation, Barrancas del Río Santa Cruz, Province of Santa Cruz, Argentina.

Species recognized in the Santa Cruz Formation in this paper. P. strepens, P. pumilus Ameghino, 1887, P. giganteus Ameghino, 1894, P. nanus Ameghino, 1898, and P. ferox Ameghino 1891a.

Peltephilus pumilus Ameghino, 1887

Figure 3.1

Type specimen. MACN-A 866-870 (Mones, 1986).

Referred material. See Appendix 1.

Geographic distribution. BB and SBB.

Description. The osteoderms collected are approximately intermediate in size compared to those of the Peltephilus species considered. Those of the movable bands vary from
9.03-11.45 $\mathrm{mm}$ in width, and $11.46-15.12 \mathrm{~mm}$ in length (Fig. 3.1). The osteoderms of P. nanus are $c a .30 \%$ smaller; those of $P$. ferox and $P$. giganteus are at least $20 \%$ larger, whereas those of $P$. strepens are 40 to $50 \%$ larger. The superficial surface is rough; there is a row of moderately developed tubercles in the anterior part, and posterior to it two pair of large and oval foramina (1.2 to $1.7 \mathrm{~mm} \times 1.3$ to 1.8 $\mathrm{mm})$, separated from each other by a narrow septum.

\section{Peltephilus sp.}

Referred material. See Appendix 1.

Geographic distribution. BB and SBB.

$$
\begin{aligned}
& \text { Family "Dasypodidae" Gray, } 1821 \\
& \text { Subfamily “DasypodinaE" Gray, } 1821 \\
& \text { Tribe Stegotheriını Ameghino, } 1889
\end{aligned}
$$

Genus Stegotherium Ameghino, 1887

Type species. Stegotherium tessellatum Ameghino, 1887. Santa Cruz Formation, Barrancas del Río Santa Cruz, Province of Santa Cruz, Argentina.

Species recognized in the Santa Cruz Formation in this paper. St. tessellatum, St. simplex (Ameghino, 1887), St. notohippidensis González Ruiz and Scillato-Yané, 2009, St. tauberi González and Scillato-Yané, 2008.

Comments. The holotype of Stegotherium simplex is a mandibular portion with only two teeth and it is lost (Mones 1986, p. 231). Scott's photographic album of fossil specimens that this researcher examined in Argentina (Vizcaíno et al., 2017, suppl. files, appendix 1, p. 1b, figs. 168 and 169) illustrates a mandibular fragment labeled as the type of St. simplex that broadly coincides with the original description of Ameghino (1887). Unfortunately, the image is insufficiently clear to allow determination of whether the condition of its anterior part is due to loss of its teeth or corresponds to the presence of predental ridges described by Vizcaíno (1994) in the skulls and mandibles of St. tessellatum. According to Fernicola and Vizcaíno (2008), if the latter were the case, then the presence of two teeth in St. simplex vs. six in St. tessellatum would support the recognition of two different genera. 
(1)

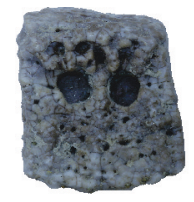

(7)

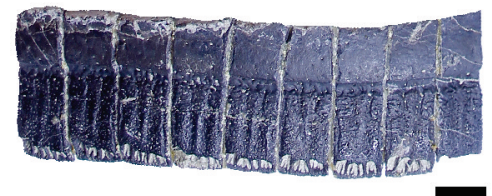

(9)

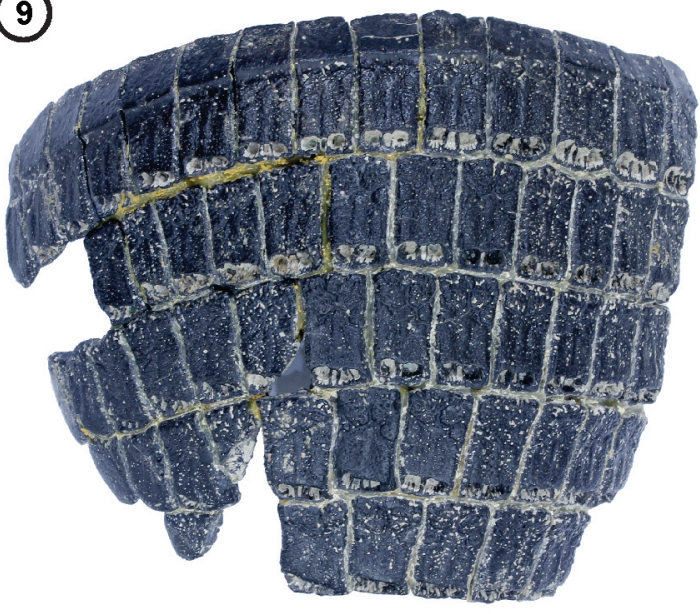

(10)

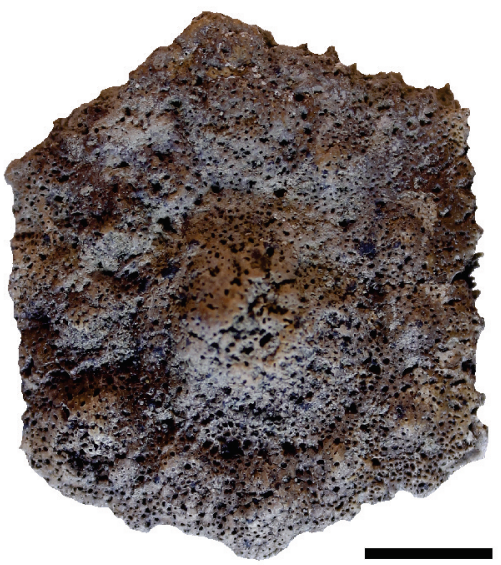

(4)

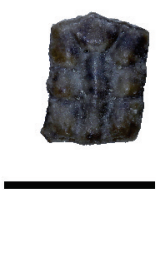

(8)
(6)

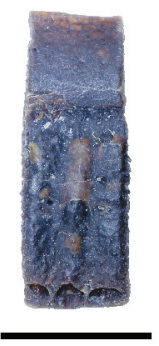

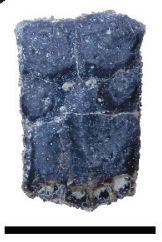
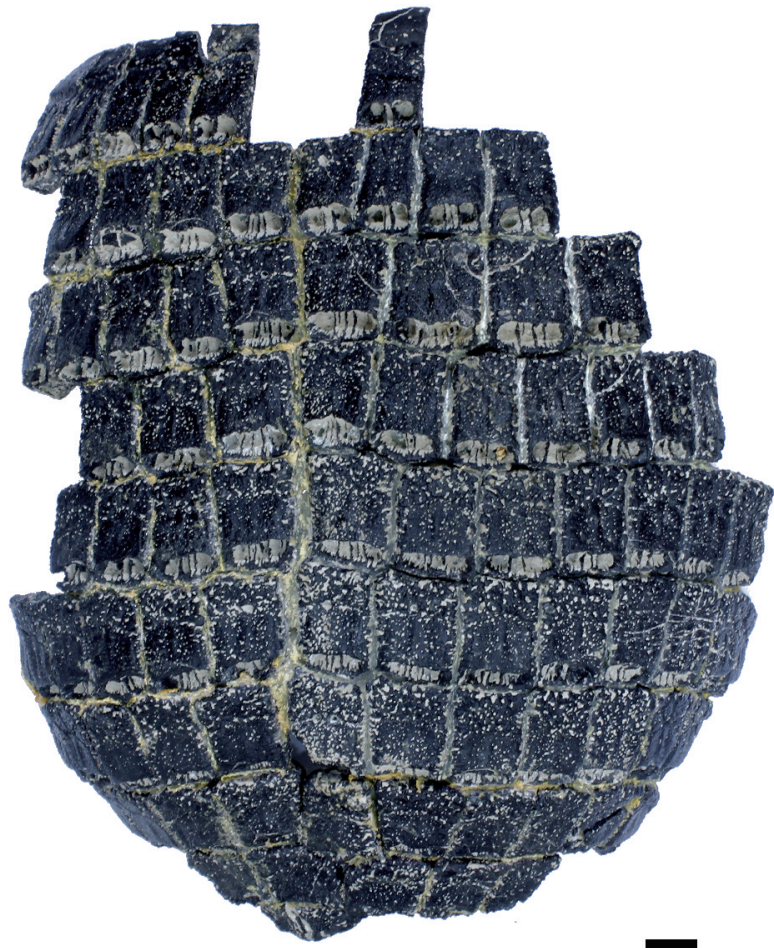

(11)

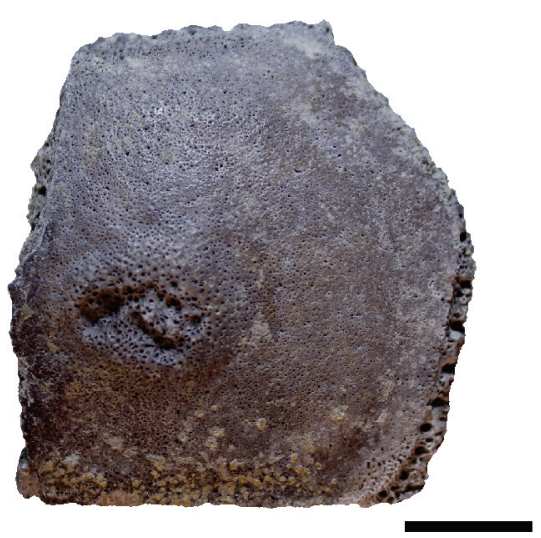

Figure 3. 1, Peltephilus pumilus, MPM-PV 20832, osteoderm of the moveable band; 2, Stegotherium tessellatum, MPM-PV 20832, 0steoderm of the moveable band; 3-4, Prozaedyus proximus, MPM-PV 20859; 3, osteoderm of the moveable band; 4, fixed osteoderm; 5-6, Stenotatus patagonicus, MPM-PV 20946; 5, osteoderm of the moveable band; 6, fixed osteoderm; 7-9, Proeutatus oenophorus, MPM-PV 21023; 7, portion of the moveable band; 8-9, pelvic shield; 10, Cochlops muricatus, MPM-PV 21071, osteoderm; 11, Eucinepeltus Sp., MPM-PV 21091 cephalic shield osteoderm. Scale bars $=10 \mathrm{~mm}$. 
Stegotherium tessellatum Ameghino, 1887

Figure 3.2

Lectotype. MACN-A 781 (Fernicola and Vizcaíno, 2008).

Paralectotype. MACN-A 782-785 (Fernicola and Vizcaíno, 2008).

Referred material. See Appendix 1.

Geographic distribution. BB.

Description. The three osteoderms assigned to this species are similar in size compared to those of the Stegotherium considered here. Those of the moveable bands vary from 4.48 to $5.53 \mathrm{~mm}$ in width, and from 9.13 to $12.28 \mathrm{~mm}$ in length (Fig. 3.2). These osteoderms have a rough superficial surface that lacks the pronounced longitudinal ridge (YPMVPPU 15565) surrounded by a large number of foramina present in St. tauberi. In the anterior part, there is a large foramen, whereas in St. notohippidensis (MLP 84-III-5-10) there are at least two.

\author{
Subfamily "EuphractinaE" Winge, 1923 \\ Tribe "Euphractinı" Winge, 1923
}

Genus Prozaedyus Ameghino, 1891a

Type species. Prozaedyus proximus (Ameghino, 1887). Santa Cruz Formation, Barrancas del Río Santa Cruz, Province of Santa Cruz, Patagonia, Argentina.

Species recognized in the Santa Cruz Formation in this paper. Pr. proximus.

Comments. Based on size, Scott (1903) recognized, with reservation, two species of Prozaedyus: Pr. proximus and Pr. exilis (Ameghino, 1887). However, several of the metric differences noted by Scott (1903) do not support specific distinction; for example, the "skull length on medial basal line" is $55 \mathrm{~mm}$ in Pr. exilis and $56 \mathrm{~mm}$ in Pr. proximus, whereas the "skull extreme length" is $66 \mathrm{~mm}$ in Pr. exilis and 70 mm in Pr. proximus (Scott, 1903, p. 77, 79 respectively). Concerning this last feature, in Chaetophractus vellerosus (Gray, 1865) the value measured in MACN-Ma 50.39 is 60 $\mathrm{mm}$ and in MACN-Ma 14.821 is $67.2 \mathrm{~mm}$. With respect to the mandible, Scott (1903) mentioned that the toothless portion of the mandible in Pr. exilis is $6 \mathrm{~mm}$, while it is about $5.3 \mathrm{~mm}$ in Pr. proximus. Once again, these differences are minimal and this feature may vary within an individual. For example, in Chaetophractus vellerosus (MACN-Ma 48.360) it length is $3.1 \mathrm{~mm}$ in the left dentary and $4.1 \mathrm{~mm}$ in the right one. Finally, with regard to the superficial morphology of the osteoderms, Scott (1903, p. 77) considered the differences between Pr. proximus and Pr. exilus as only minor and, probably, inconsistent. According to Scott (1903) a moveable band osteoderm of Pr. exilis is $4 \mathrm{~mm}$ in width by $15 \mathrm{~mm}$ in length, while in Pr. proximus it is $5.5 \mathrm{~mm}$ in width by $20 \mathrm{~mm}$ length (Scott, 1903, p. 77, 78 respectively). In Zaedyus pichiy (Desmarest, 1804) the osteoderms of the moveable bands vary from 4.47 to $5.87 \mathrm{~mm}$ in width and from 16.45 to 22.00 $\mathrm{mm}$ in length. With respect to the fixed osteoderms, the measurements provided by Scott (1903, p. 77, 78, respectively) for Pr. exilis are $6 \mathrm{~mm}$ in width by $8 \mathrm{~mm}$ in length, and $6 \mathrm{~mm}$ in width by $9 \mathrm{~mm}$ in length for Pr. proximus. In Zaedyus pichiy (MACN-Ma 25295) the fixed osteoderms vary from 4.99 to $7.73 \mathrm{~mm}$ in width and from 7.90 to $9.60 \mathrm{~mm}$ in length. Indeed, the metric and morphological differences provided by Scott (1903) for these two species are slight and within the range of variation of different species of other cingulates such as the extant Chaetophractus vellerosus and Zaedyus pichiy. Thus, only the type species, Prozaedyus proximus, is recognized here.

Prozaedyus proximus (Ameghino, 1887)

Figure 3.3-4

Type specimen. Lost (Mones, 1986).

Referred material. See Appendix 1.

Geographic distribution. BB, SBB, and $\mathrm{YH}$.

Description. The collected osteoderms assigned to this species are smaller than in Stenotatus and their overall morphology coincides with the description of the osteoderms of Pr. proximus provided by Ameghino $(1887,1889)$ and Scott (1903). The osteoderms of the moveable bands vary from 4.02 to $4.89 \mathrm{~mm}$ in width and from 12.98 to $18.89 \mathrm{~mm}$ in length (Fig. 3.3). The superficial surface of the moveable band osteoderms bears three convex longitudinal figures of similar width, separated by two longitudinal sulci, which extend posteriorly to reach its posterior border. The sulci are parallel along their anterior two-thirds but tend to converge toward each other posteriorly. The lateral figures are divided by two to four transverse sulci each, resulting in three to 
five pairs of small lateral figures. Generally, a very small foramen is present at each intersection between the main and the transverse sulci. Along the posterior border there are two foramina, larger than those on the superficial surface, that are usually aligned with the main sulci. Some osteoderms have three posterior foramina. The fixed osteoderms vary from 4.73 to $6.58 \mathrm{~mm}$ in width, and from 8.46 to $8.93 \mathrm{~mm}$ in length (Fig. 3.4). Each fixed osteoderm bears an elongated main figure surrounded by four to eight markedly convex peripheral figures. An external foramen is generally present at the intersection between the main figure and each radial sulcus. Along the posterior margin are two piliferous foramina, each aligned with the one of the sulci that define the main figure; a third foramen may be present.

Family "DAsYPodidaE" Gray, 1821

Subfamily "EuphractinaE" Winge, 1923

Tribe "EutATINI" Bordas, 1933

Genus Stenotatus Ameghino, 1891a

Type species. Stenotatus patagonicus (Ameghino, 1887). Santa Cruz Formation, Barrancas del Río Santa Cruz, Province of Santa Cruz, Argentina.

Species recognized in the Santa Cruz Formation in this paper. S. patagonicus and S. hesternus (Ameghino, 1889).

Stenotatus patagonicus (Ameghino, 1887)

Figure 3.5-6

Type specimen. Lost (Mones, 1986).

Referred material. See Appendix 1.

Geographic distribution. BB, SBB, and $\mathrm{YH}$.

Description. The collected osteoderms assigned to this species are larger than Prozaedyus and smaller than Proeutatus. The osteoderms of the moveable bands vary from 5.29 to $7.33 \mathrm{~mm}$ in width and from 17.63 to $21.05 \mathrm{~mm}$ in length (Fig. 3.5). The superficial surface of the moveable band osteoderms bears three convex longitudinal figures that are defined by two longitudinal sulci, which extend posteriorly to reach the posterior border. The main figure is somewhat wider than the two figures, one on either side, that flank it. The main figure is undivided, while the two lateral figures may be divided by one or two transverse sulci into two or three smaller figures, respectively. The posterior border of the moveable band osteoderms bears two types of piliferous foramina, differing in size and position and alternating with each other. The three or four large posterior foramina are located less peripherally than the small foramina, each of which lies midway between two large foramina. Small piliferous foramina are present at the intersection between the main and the radial sulci. By contrast, in $S$. hesternus these foramina are conspicuous. The fixed osteoderms vary from 7.20 to $8.69 \mathrm{~mm}$ in width and from 11.54 to $12.99 \mathrm{~mm}$ in length (Fig. 3.6). They bear an elongated main figure, which does not reach the posterior border and may be anteriorly wider or of constant width. The anterior and lateral regions are divided by three to five radial sulci that delimit four to six peripheral figures surrounding the main figures. The posterior two peripheral figures on each side contact each other at the midline of the osteoderm, forming a larger U-shaped figure. In some osteoderms this contact is narrow, whereas it is wide in others. The pattern of the foramina at the posterior border is similar to that of the moveable osteoderms, but there may be as many as six large and five small foramina. The latter are present at the intersection between the main and the radial sulci.

\section{Genus Proeutatus Ameghino, 1891a}

Type species. Proeutatus oenophorus (Ameghino, 1887). Santa Cruz Formation, Barrancas del Río Santa Cruz, Province of Santa Cruz, Patagonia, Argentina.

Species recognized in the Santa Cruz Formation in this paper. Pro. oenophorus, Pro. deleo (Ameghino, 1891b), and Pro. carinatus (Ameghino, 1891b).

Comments. Scott (1903) recognized five species, Pro. oenophorus, Pro. lagena (Ameghino, 1887), Pro. carinatus, Pro. deleo, and Pro. robustus Scott, 1903. This author considered the morphology of the osteoderms of Pro. oenophorus and Pro. lagena identical (Scott, 1903, p. 65), and that neither species exhibits marked differences compared with Pro. robustus (Scott, 1903, p. 43). Scott (1903) noted that the feature that best differentiates Pro. lagena from Pro. oenophorus is the presence, in the former, of an elongated and tubular rostrum that widens anteriorly but without 
achieving the spatulate condition present in the latter. However, the value of this difference for specific distinction is unreliable, as both conditions occur in adult specimens of the extant Euphractus sexcintus (Linnaeus, 1758) (MACN-Ma 50.121, MACN-Ma 34.592). Another difference noted by Scott (1903) refers to the presence of a longer mandibular symphysis in Pro. lagena $(22 \mathrm{~mm})$ with respect to Pro. oenophorus (15 mm). However, in E. sexcinctus the symphysis ranges between 17 (MACN-Ma 42.104) and $25 \mathrm{~mm}$ in length (MACN-Ma 31.88). Scott (1903) also reported that Pro. robustus is characterized by a larger size and notably heavier proportions compared to Pro. oenophorus. The tables of measurements of the femur provided by Scott (1903) for these two species reveals that the difference in size of these two species is approximately $10-15 \%$. This difference is within the range of variation of several other cingulates species (e.g., E. sexcinctus $\sim 12 \%$, Fernicola pers. obs.). The status of Pro. lagena and Pro. robustus with respect to each other and whether either is distinguishable specifically from Pro. oenophorus is uncertain. In the context of the present report, a decision cannot be taken, because the type specimen of Pro. lagena is lost (Mones, 1986) and the authors were unable to access part of the holotype of Pro. robustus (YPM-VPPU 15214). Clearly, the metric and morphological differences noted by Scott (1903) in differentiating among the species are within the range of variation of at least one species of living armadillos, Euphractus sexcinctus (see above), and their taxonomic utility is doubtful. As well, the osteoderms of these three species, as described by Scott (1903), cannot be distinguished by the current authors. It is worth noting, in this regard, that the carapace of Pro. robustus on which Scott (1903, p. VIII; YPM-VPPU 15957) based his description was assigned to this species with a question mark by the author himself. In this context, we have only compared the superficial morphology of the osteoderms among Pro. oenophorus, Pro. deleo and Pro. carinatus, which morphology is in fact different (see below).

\section{Proeutatus oenophorus (Ameghino, 1887)}

Figure 3.7-9

Type specimen. Lost (Mones, 1986).

Referred material. See Appendix 1.
Geographic distribution. BB, SBB, and $\mathrm{YH}$.

Description. The osteoderms assigned to Proeutatus oenophorus are similar in size to other species of this genus. Those of the moveable bands vary from 9.22 to $10.44 \mathrm{~mm}$ in width and 27.80 to $32.5 \mathrm{~mm}$ in length (Fig. 3.7). The superficial surface of the moveable band osteoderms is rugose and bears a main lageniform figure, narrow on the middle part of the osteoderm and widening posteriorly. The main figure bears a prominent keel along its midline and lateral figure lies on either side of the narrowed part of the main figure. The external surface of the osteoderms is pierced posteriorly by three or four large foramina, separated from each other and from the posterior margin of the osteoderms by a thin bony septum. The fixed osteoderms vary from 10.84 to $15.26 \mathrm{~mm}$ in width and from 18.87 to $19.34 \mathrm{~mm}$ in length (Figs. 3.8-9). They are rectangular with a distinctly lageniform main figure. By contrast in the fixed osteoderm of Pro. deleo (MACN-A 4800-4802; see Vizcaíno et al., 2017, suppl. files, appendix 1, p. 34, fig. 71c) this main figure is much less marked. The midline of the lageniform main figure of Pro. oenophorus shows a well-developed keel, but the keel in Pro. carinatus (MACN-A 561; see Vizcaíno et al., 2017, suppl. files, appendix 1, p. 34, fig. 70) is even more prominent. Anteriorly, there are one or two well-developed figures, and a lateral figure is present on either side of the narrow part of the main figure. The posterior part of the osteoderm is similar to that described for the moveable osteoderms.

Family Propalaehoplophoridae Ameghino, 1891c

Genus Cochlops Ameghino, 1889

Type species. Cochlops muricatus Ameghino, 1889. Santa Cruz Formation, Río Chico, Province of Santa Cruz, Argentina.

Species recognized in the Santa Cruz Formation in this paper. Cochlops muricatus.

Comments. Scott (1903) recognized two species, Cochlops muricatus and Cochlops debilis Ameghino, 1891a. Cochlops muricatus was based on osteoderms of the carapace with the central figure raised into a high cone, while the peripheral figures form a ring of lower conical tubercles around it (Ameghino, 1889). Cochlops debilis was based on a mandible (Ameghino, 1891a), but Scott (1903) assigned a skull with a 
cephalic shield to this species; in other words, based on nonhomologous elements. The specimens assigned by Ameghino (1891a) and Scott (1903) to Cochlops debilis lack carapace osteoderms, and it is not therefore possible to confirm this taxonomic assignment. In this context, we have only recognized Cochlops muricatus.

\section{Cochlops muricatus Ameghino, 1889}

Figure 3.10

Type specimen. Lost. According to Mones (1986) the type is MACN-A 4751, but this specimen is a mandible and Ameghino (1889) only described osteoderms. These osteoderms, despite extensive searches, have not been found in the Ameghino collection.

Referred material. See Appendix 1.

Geographic distribution. BB and $\mathrm{YH}$.

Description. The osteoderms bear marked central and peripheral figures; in some cases, the central figure raised into a high cone reaching $20 \mathrm{~mm}$ in height (Fig. 3.10). This kind of osteoderm is located in the posterodorsal region of the carapace.

\section{Genus Eucinepeltus Ameghino, 1891a}

Type species. Eucinepeltus petesatus Ameghino, 1891a. Santa Cruz Formation, Cerro Observatorio, Province of Santa Cruz, Argentina.

Species recognized in the Santa Cruz Formation in this paper. Eu. petesatus, Eu. crassus Scott, 1903, and Eu. complicatus Brown, 1903.

Comments. Scott (1903) recognized three species, Eu. petesatus, Eu. crassus, and Eu. complicatus. The shape and number of osteoderms of the cephalic shield were used to diagnose these species. Unfortunately, only isolated cephalic shield osteoderms were collected by the MLPMACN-Duke expeditions, so it is not possible to evaluate the number of osteoderms and shape of the cephalic shield.

\section{Eucinepeltus sp.}

Figure 3.11

Referred material. See Appendix 1.

Geographic distribution. BB and SBB.
Description. The osteoderms of the cephalic shield recovered by us show the typical fossa in middle of the superficial surface, which is a diagnostic feature of this genus (Ameghino, 1891a; Scott, 1903; Brown, 1903) (Fig. 3.11).

\section{PropalaEhoplophORIDAE indet.}

Referred material. See Appendix 1.

Geographic distribution. BB, SBB, and $\mathrm{YH}$.

\section{TAXONOMIC RICHNESS}

According to the taxonomic assignments presented here of the new specimens from the SCR, five species of armadillos are recognized in BB, Peltephilus pumilus, Stegotherium tessellatum, Stenotatus patagonicus, Proeutatus oenophorus, and Prozaedyus proximus, and two glyptodonts, Cochlops muricatus and Eucinepeltus sp. In SBB we recognized four armadillos, Peltephilus pumilus, Stenotatus patagonicus, Proeutatus oenophorus, and Prozaedyus proximus, and one glyptodont Eucinepeltus sp., while in $\mathrm{YH}$ the armadillos Stenotatus patagonicus, Proeutatus oenophorus, and Prozaedyus proximus, and the glyptodont Cochlops muricatus (Tab. 1) are present.

The first level comparison, that between the taxa reported from the RSC by Ameghino $(1887,1889)$ with those based on the new specimens reported here, reveals the presence of the same five genera of armadillos initially reported by Ameghino (1887): Stegotherium, Peltephilus, Proeutatus, Prozaedyus, and Stenotatus. Remains assignable to the glyptodont Propalaehoplophorus, noted by Ameghino (1887), were not recovered during the course of the recent expeditions to the RSC; however, the first record from this area of Eucinepeltus and Cochlops are reported. At the specific level, the taxonomic richness of the armadillos is similar to that mentioned by Ameghino (1887, 1889), five species, with Peltephilus strepens being the only species not recorded. Regarding the glyptodonts, the species richness increased from one to at least three taxa (Tab. 2).

In the second level of comparison, the richness among $\mathrm{BB}, \mathrm{SBB}$, and $\mathrm{YH}$ based only on the new remains, seven cingulate species of (Tab. 1) are recognized from BB. The difference between BB and SBB is the absence in the latter of Stegotherium tessellatum and Cochlops muricatus. The differ- 
$\overline{\text { TABLE } 1 \text { - Distribution of cingulates in Barrancas Blancas, Segunda }}$ Barrancas Blancas, and Yaten Huageno recorded in this contribution

\begin{tabular}{|c|c|c|c|}
\hline Taxa & $\begin{array}{c}\text { Barrancas } \\
\text { Blancas }\end{array}$ & $\begin{array}{c}\text { Segundas } \\
\text { Barrancas } \\
\text { Blancas }\end{array}$ & $\begin{array}{c}\text { Yaten } \\
\text { Huageno }\end{array}$ \\
\hline Peltephilus pumilus & $x$ & $x$ & \\
\hline Stegotherium tessellatum & $x$ & & \\
\hline Stenotatus patagonicus & $x$ & $x$ & $x$ \\
\hline Proeutatus oenophorus & $x$ & $x$ & $x$ \\
\hline Prozaedyus proximus & $x$ & $x$ & $x$ \\
\hline Cochlops muricatus & $x$ & & $x$ \\
\hline Eucinepeltus $s p$. & $x$ & $x$ & \\
\hline Total number of species & 7 & 5 & 4 \\
\hline
\end{tabular}

ence between $\mathrm{BB}$ and $\mathrm{YH}$ is the absence in $\mathrm{YH}$ of Peltephilus pumilus, Stegotherium tessellatum, and Eucinepeltus sp. Finally, SBB and YH shared the following taxa: Stenotatus patagonicus, Proeutatus oenophorus, and Prozaedyus proximus, while Peltephilus pumilus and Eucinepeltus sp. are in SBB, and Cohlops muricatus in $\mathrm{YH}$ (Tab. 1).

The third level of analysis, excluding the taxa that we considered doubtful (see above), reveals that the seven genera recorded along the RSC have been recorded in other areas (Tab. 2). The only difference is the absence of Vetelia and Propalaehoplophorus from the outcrops along the RSC. Vetelia was recorded by Ameghino (1891c) based on material collected from exposures northwest of the RSC, and assigned by (Ameghino, 1902) to the "Notohippidian" - the oldest Santacrucian faunal assemblage according to Marshall et al. (1983) —. Fernicola et al. (2009) reported this genus from the SCF in the Atlantic coast. At the specific level, only seven species were recorded of the 21 recognized from the SCF (Tabs. 1, 2). Among peltephilines, this report records Peltephilus pumilus and Peltephilus strepens, which were mentioned by Ameghino (1887) for the RSC. In addition to these two species, $P$. ferox and $P$. nanus have also been recorded from the Atlantic coast (see Vizcaíno et al., 2012c). From the western area, Ameghino (1900-02) listed the peltephilines $P$. giganteus and $P$. pumilus. The first species and $P$. ferox have also been reported from the central area (see Vizcaíno et al., 2012c). Regarding Stegotherium, the only recorded species in the RSC is Stegotherium tessellatum, which is also present in the western (Ameghino, 1887, 1900-02, 1906). González Ruiz and Scillato-Yané (2008, 2009) identified two new stegotherines: Stegotherium tauberi form the eastern and Stegotherium notohippidensis from the western areas. Among eutatines Stenotatus patagonicus is recorded all along the SCF from the eastern to the western areas (Ameghino, 1887, 1900-02, 1906), whereas S. herternus has only been reported from the Atlantic coast (Vizcaino et al., 2012c). With regard to Proeutatus, Pro. oenophorus has been reported throughout the SCF, Pro. deleo from the western region and the Atlantic coast, and Proeutatus carinatus only from the latter region (Vizcaíno et al., 2012c). The euphractine Prozaedyus proximus has been recorded from all outcrops of the SCF. With respect to glyptodonts, Propalaeohoplophorus australis and Cochlops muricatus have been noted from all three areas, while Eucinepeltus was reported in the RSC and the Atlantic coast (Vizcaíno et al., 2012c).

\section{DISCUSSION AND CONCLUSION}

The new specimens collected with precise geographic provenance allowed evaluation of the taxonomic richness of the cingulates of the SCF outcropping along the southern banks of the RSC. In total, seven species, each belonging to different genera, were recognized here (Tab. 1).

All the genera of armadillos reported by Ameghino (1887) and six of the seven species of this group were recovered by the MLP-MACN-Duke expeditions. Among glyptodonts, the presence of Eucinepeltus and Cochlops is novel, but remains of Propalaehoplophorus, reported by Ameghino (1887), were not recovered. Indeed, at the species level, the difference between the composition and taxonomic richness between the remains noted by Ameghino (1887) and those reported here are very few, and is likely due to sampling. The presumed absence of Propalaehoplophorus remains may be an artifact due to the lack of diagnostic features in the material collected by us. The osteoderms that we assigned to Eucinepetus and Cochlops correspond to two small parts of the exoskeleton: the cephalic shield and a small portion located in the posterior region of the carapace, respectively. The osteoderms that were not assigned to 
TABLE 2 - Distribution of cingulates of the Santa Cruz Formation in different areas of the Province of Santa Cruz (see Systematic Paleontology)

\begin{tabular}{|c|c|c|c|}
\hline Taxa & Eastern & Central & Western \\
\hline Peltephilus strepens & $x^{3}$ & $x^{\prime}$ & \\
\hline Peltephilus pumilus & $X^{7}$ & $X^{1}$ & $x^{2}$ \\
\hline Peltephilus giganteus & & $x^{3}$ & $x^{2}$ \\
\hline Peltephilus nanus & $x^{3}$ & & \\
\hline Peltephilus ferox & $x^{3}$ & $x^{3}$ & \\
\hline Stegotherium tessellatum & & $x^{1}$ & $x^{2}$ \\
\hline Stegotherium tauberi & $x^{4}$ & & \\
\hline Stegotherium notohippidensis & & & $x^{5}$ \\
\hline Stenotatus patagonicus & $x^{3}$ & $x^{1}$ & $x^{2}$ \\
\hline Stenotatus hesternus & $x^{3}$ & & \\
\hline Proeutatus oenophorus & $x^{3}$ & $x^{1}$ & $x^{2}$ \\
\hline Proeutatus deleo & $x^{3}$ & & $x^{2}$ \\
\hline Proeutatus carinatus & $x^{3}$ & & \\
\hline Prozaedyus proximus & $x^{3}$ & $X^{1}$ & $x^{2}$ \\
\hline Vetelia puncta & $x^{6}$ & & $x^{2}$ \\
\hline Propalaehoplophorus australis & $x^{3}$ & $x^{1}$ & $x^{2}$ \\
\hline Propalaehoplophorus minor & $x^{8}$ & & \\
\hline Cochlops muricatus & $x^{3}$ & $x^{9}$ & $x^{2}$ \\
\hline Eucinepeltus petesatus & $x^{3}$ & $x^{9}$ & \\
\hline Eucinepeltus crassus & $x^{7}$ & & \\
\hline Eucinepeltus complicatus & $x^{8}$ & & \\
\hline Total number of species & 18 & 12 & 11 \\
\hline
\end{tabular}

X': Ameghino (1887); X: Ameghino (1900-02); X3: Vizcaíno et al. (2012); X4: González Ruiz and Scillato-Yané (2009); X5: González Ruiz and Scillato-Yané (2008); $X^{6}$ : Fernicola et al. (2009); $X^{7}$ : Scott (1903); $X^{8}$ Brown (1903); $X^{9}$ : Fernicola and Vizcaino, this work

Eucinepeltus or Cochlops can only be assigned to Propalaehoplophoridae due to the similarity among the three genera in osteoderm morphology over a large part of the carapace.

The second level of analysis considers the taxonomic richness among the localities of the RSC (Tab. 1) based on the new remains recovered. The only difference between
BB and SBB is the presence of the armadillo Stegotherium tessellatum and the glyptodont Cochlops muricatus in the former. Stegotherium tessellatum is represented by only three osteoderms, suggesting that this species may not have been particularly abundant, thus reducing the probability of recovering its remains in other localities, which have yielded fewer specimens. The absence of Cochlops muricatus 
in SBB may, as in the case of Propalaehoplophorus, be attributable to sampling, given that this taxon has been reported in the other regions of the SCF (see below). The lower taxonomic richness registered in $\mathrm{YH}$, three armadillos and one glyptodont species, could be a due to sampling size, given that this locality is the smallest of the three. Although Carlos Ameghino claimed that this was the richest fossiliferous site in the area (letter 166 in Torcelli, 1935; Vizcaíno, 2011), in 1889 Clemente Onelli had the opposite impression, recovering only a few armadillo osteoderms and a toxodont skull over several days (Vizcaíno et al., 2013; Brinkman and Vizcaíno, 2014). The new collections in YH confirm Onelli's view.

The third level of analysis considers the taxonomic richness of cingulates recognized from the SCF in the RSC and other central areas, such as Río Chalía, compared with that previously recognized in the western and eastern localities of the SCF (Tab. 2). All the genera recorded in the western and eastern areas are also known from the central area, with the exception of Vetelia; indeed, this cingulate is scarce in the SCF. Fernicola et al. (2009) reported the first and only record of this genus from the coast of the Province of Santa Cruz, $3 \mathrm{~km}$ south of the mouth of the Río Coyle, based on a single osteoderm. Given this circumstance, evaluation of its absence in the central areas is not particularly meaningful. At the specific level, the taxonomic differences compared with other regions of the SCF are more pronounced. In the three areas defined for the SCF there are at least 21 species of cingulates, of which six are glyptodonts (Tab. 2). The highest taxonomic richness is recorded in the eastern region (Atlantic coast), while in the other two regions it is approximately one third lower (Tab. 2), a difference that may be due to the much more intensive collecting efforts along the Atlantic coast (Vizcaíno et al., 2013).

The number of shared species among the three areas decreases from east to west (east-center: ten spp.; centerwest: eight spp.; east-west: six spp.). This taxonomic gradient may coincide with an environmental gradient produced by the elevation of the Andes. Evaluation of this hypothesis requires analyses of specific climatically or environmentally sensitive morphological features such as, for example, piliferous foramina size (Ciancio et al., 2017), and of exhaustive abiotic and biotic evidence, as by Kay et al. (2012).

\section{ACKNOWLEDGMENTS}

We thank the Dirección de Patrimonio Cultural and the MPM (Río Gallegos, Province of Santa Cruz) for permission for the fieldwork in Santa Cruz, and all people involved in the field work. We are grateful to the curators M. Reguero (MLP), L. Chornogubsky (MACN) and M. Ezcurra (MACN), and former curator A. Kramarz (MACN) for making available the collections under their care. Gerry De luliis and two anonymous reviewers made important comments and suggestions that helped to improve this work. This is a contribution to projects PIP 781, PICT 2013-0389, PICT 2017-1081, UNLP N/867, CBLUJ 0000030-18, National Science Foundation 0851272 and 1348259, and National Geographic Society 9167-12 (R.F. Kay).

\section{REFERENCES}

Aguiar, J.M., and Fonseca, G.A.B. 2008. Conservation status of Xenarthra. In: S.F. Vizcaíno, and W.J. Loughry (Eds.), The Biology of the Xenarthra. University Press of Florida, Gainesville, p. 215231.

Ameghino, F. 1887. Enumeración sistemática de las especies de mamíferos fósiles coleccionados por Carlos Ameghino en los terrenos eocenos de la Patagonia y depositados en el Museo de La Plata. Boletín del Museo de La Plata 1: 1-26.

Ameghino, F. 1889. Contribución al conocimiento de los mamíferos fósiles de la República Argentina. Actas de la Academia Nacional de Ciencias de Córdoba 6: 1-1027.

Ameghino, F. 1891a. Nuevos restos de mamíferos fósiles descubiertos por Carlos Ameghino en el Eoceno inferior de la Patagonia Austral. Especies nuevas, adiciones y correcciones. Revista Argentina de Historia Natural 1: 286-328.

Ameghino, F. 1891b. Mamíferos y aves fósiles argentinas. Especies nuevas, adiciones y correcciones. Revista Argentina de Historia Natural 1: 240-259.

Ameghino, F. 1891c. Caracteres diagnósticos de cincuenta especies nuevas de mamíferos fósiles argentinos. Revista Argentina de Historia Natural 1: 129-167.

Ameghino, F. 1891d. Observaciones críticas sobre los mamíferos eocenos de la Patagonia austral. Revista Argentina de Historia Natural 1: 328-382.

Ameghino, F. 1894. Énumération synoptique des espèces de mammifères fossiles des formations éocènes de Patagonie. Coni é hijos, Buenos Aires, $196 \mathrm{p}$.

Ameghino, F. 1895. Sur les édentés fossiles de l'Argentine: Examen critique, revision et correction de l'ouvrage de R. Lydekker: The extint edentates of Argentina. Revista del Jardín Zoológico de Buenos Aires 3: 97-192.

Ameghino, F. 1898. Primera sinopsis geológico-paleontológica. $2^{\circ}$ Censo de la República Argentina 1: 111-255.

Ameghino, F. 1900-1902. L'âge des formations sédimentaires de Patagonie. Anales de la Sociedad Científica Argentina 50: 109130, 145-165,209-229; 51: 20-39, 65-91; 52: 189-197, 244-250; 54: 161-180, 220-249, 283-342.

Ameghino, F. 1906. Les formations sédimentaires du Créetacé Superieur et du Tertaire de Patagonie avec un parallele entre leurs faunes mammalogiques et celles de l'ancien continent. Anales del Museo Nacional de Buenos Aires 15: 1-568.

Ameghino, F. 1920. Sur les édentés fossiles de l'Argentine: Examen critique, revision et correction de l'ouvrage de R. Lydekker: The extint edentates of Argentina. Revista del Jardín Zoológico de Buenos Aires. In: A.J. Torcelli (Ed.), Obras completas y correspondencia científica de Florentino Ameghino. Taller de Impresiones Oficiales del Gobierno de la Provincia de Buenos Aires, La Plata, 
Volumen 11, p. 603-909.

Bordas, A.F. 1936. Los Peltateloidea de la colección Ameghino. Peltephiloda. (Infraorden de los Xenarthra). Physis 12: 1-18.

Bordas, A.F. 1938. Sobre un nuevo Peltephiloda del Trelewense. Physis 12: 267-277.

Brinkman, P.D., and Vizcaíno, S.F. 2014. Clemente Onelli's sketch map and his first-hand, retrospective account of an early fossil-hunting expedition along the Río Santa Cruz, southernPatagonia, 1888-1889. Society for the Bibliography of Natural History; Archives of natural history 41: 326-337.

Brown, B. 1903. A new Species of fossil Edentate from the Santa Cruz Formation of Patagonia. Bulletin of the American Museum of Natural History 19: 453-457.

Castro, M.C., Ciancio, M.R., Pacheco, V., Salas-Gismondi, R.M., Bostelmann, J.E., and Carlini, A.A. 2015. Reassessment of the hairy long-nosed armadillo "Dasypus" pilosus (Xenarthra, Dasypodidae) and revalidation of the genus Cryptophractus Fitzinger, 1856. Zootaxa 3947: 30-48.

Ciancio, M.R., Carlini, A.A., Campbell, K.E. Jr., and Scillato-Yané, G.J. 2013. New Paleogene cingulates (Mammalia, Xenarthra) from Santa Rosa, Peru, and their importance in the context of South American faunas. Journal of Systematic Paleontology 11: 727-741.

Ciancio, M.R., Krmpotic, C.M., Scarano, A.C., and Epele, M.B. 2017. Internal morphology of osteoderms of extinct armadillos and its relationship with environmental conditions. Journal of Mammalian Evolution 26: 71-83.

Cobos, J.C., Rodríguez, M.F., and Panza, J.L. 2014. Hoja Geológica 5172-II, Paso Río Bote, Provincia de Santa Cruz. Boletín del Instituto de Geología y Recursos Minerales, Servicio Geológico Minero Argentino 405: 1-99.

Cuitiño, J.l., Fernicola, J.C., Kohn, M.J., Trayler, R., Naipauer, M., Bargo, M.S., Kay, R.F., and Vizcaíno, S.F. 2016. U-Pb geochronology of the Santa Cruz Formation (early Miocene) at the Río Bote and Río Santa Cruz (southernmost Patagonia, Argentina): Implications for the correlation of fossil vertebrate localities. Journal of South American Earth Sciences 70: 198-210.

Cuitiño, J.I., Fernicola, J.C., Raigemborn, M.S., and Krapovickas, V. 2019b. Stratigraphy and depositional environments of the Santa Cruz Formation (Early-Middle Miocene) along the Río Santa Cruz, southern Patagonia, Argentina. In: J.C. Fernicola, M.S. Bargo, S.F. Vizcaíno, and R.F. Kay (Eds.), Early-Middle Miocene Paleontology in the Río Santa Cruz, Southern Patagonia, Argentina. 130 years since Ameghino, 1887. Publicación Electrónica de la Asociación Paleontológica Argentina 19: 14-33.

Cuitiño, J.I., Vizcaíno, S.F., Bargo, M.S., and Aramendía, I. 2019a. Sedimentology and fossil vertebrates of the Santa Cruz Formation (early Miocene) in Lago Posadas, a sub-Andean locality of southwestern Patagonia. Andean Geology 46: 383-420.

Desmarest, A. 1804. Nouveau Dictionnaire d'Histoire Naturelle, appliquée aux arts, principalement à l'agriculture, à l'économie rurale et domestique: Par une société de naturalistes et d'agriculteurs: Avec des figures tirées des trois règnes de la nature. Vol. 24. Chez Deterville, Paris, $538 \mathrm{p}$.

Fernicola, J.C. 2008. Nuevos aportes para la sistemática de los Glyptodontia Ameghino, 1889 (Mammalia, Xenarthra, Cingulata). Ameghiniana 45: 553-574.

Fernicola, J.C., Bargo, M.S., Vizcaíno, S.F., and Kay, R.F. 2019. Historical background for a revision of the paleontology of the Santa Cruz Formation (Early-Middle Miocene) along the Río Santa Cruz, Patagonia, Argentina. In: J.C. Fernicola, M.S. Bargo, S.F. Vizcaíno, and R.F. Kay (Eds.), Early-Middle Miocene Paleon- tology in the Río Santa Cruz, Southern Patagonia, Argentina. 130 years since Ameghino, 1887. Publicación Electrónica de la Asociación Paleontológica Argentina 19: 1-13.

Fernicola, J.C., Cuitiño, J.I., Vizcaíno, S.F., Bargo, M.S., and Kay, R.F. 2014. Fossil localities of the Santa Cruz Formation (early Miocene, Patagonia, Argentina) prospected by Carlos Ameghino in 1887 revisited and the location of the Notohippidian. Journal of South American Earth Sciences 52: 94-107.

Fernicola, J.C., and Vizcaíno, S.F. 2008. Revisión del género Stegotherium Ameghino, 1887 (Mammalia, Xenarthra, Dasypodidae). Ameghinana 45: 321-332.

Fernicola, J.C., Vizcaíno, S.F., and Bargo, M.S. 2009. Primer registro de Vetelia puncta Ameghino (Xenarthra, Cingulata) en la Formación Santa Cruz (Mioceno temprano) de la costa atlántica de la provincia de Santa Cruz, Argentina. Ameghiniana 46: 77R.

Francia, A., and Ciancio, M.R. 2013. First record of Chaetophractus villosus (Mammalia, Dasypodidae) in the late Pleistocene of Corrientes Province (Argentina). Revista del Museo de La Plata 13: 1-9.

Fleagle, J.H., Perkins, M.E., Heizler, M.T., Nash, B., Bown, T.M., Tauber, A.A., Dozo, M.T., and Tejedor, M.F. 2012. Absolute and relative ages of fossil localities in the Santa Cruz and Pinturas Formations. In: S.F. Vizcaíno, R.F. Kay, and M.S. Bargo (Eds.), Early Miocene Paleobiology in Patagonia: high-latitude paleocommunities of the Santa Cruz Formation. Cambridge University Press, Cambridge, p. 41-58.

Fosdick, J.C., Grove, M., Hourigan, J.K., and Calderón, M. 2013. Retroarc deformation and exhumation near the end of the Andes, southern Patagonia. Earth and Planetary Science Letters 361: 504-517.

Ghiglione, M.C., Ramos, V.A., Cuitiño, J.I., and Varberón, V. 2016. Growth of the Southern Patagonian Andes $\left(46-53^{\circ} \mathrm{S}\right)$ and their Relation to Subduction Processes. In: A. Folguera, M. Naipauer, L. Sagripanti, M. Ghiglione, D. Orts, and L. Giambiagi (Eds.), Growth of the Southern Andes. Springer Earth System Sciences. Springer International Publishing, Switzerland doi 10.1007/978-3-31923060-3_10.

González Ruiz, L.R. 2010. [Los Cingulata (Mammalia, Xenarthra) del Mioceno temprano y medio de Patagonia (edades Santacrucense y "Friasense") revisión sistemática y consideraciones bioestratigráficas. PhD Thesis, Facultad de Ciencias Naturales y Museo, Universidad Nacional de La Plata, La Plata, 471 p. Unpublished.].

González Ruiz, L.R., and Scillato-Yané, G.J. 2008. Una nueva especie de Stegotherium (Xenarthra, Dasypodidae, Stegotheriini) del Mioceno de la provincia de Santa Cruz. Ameghinana 45: 641648.

González Ruiz, L.R., and Scillato-Yané, G.J. 2009. A new Stegotheriini (Mammalia, Xenarthra, Dasypodidae) from the "Notohippidian" (early Miocene) of Patagonia. Neues Jahrbuch für Mineralogie, Geologie und Paläontologie 252: 81-90.

Gray, J.E. 1865. Revision of the genera and species of entomophagous Edentata, founded on the examination of the specimens in the British Museum. Proceedings of the Zoological Society of London 1865: 359-386.

Kay, R.F., Vizcaíno, S.F., and Bargo, M.S. 2012. A review of the paleoenvironment and paleoecology of the Miocene Santa Cruz Formation. In: S.F. Vizcaíno, R.F. Kay, and M.S. Bargo (Eds.), Early Miocene Paleobiology in Patagonia: High-Latitude Paleocommunities of the Santa Cruz Formation. Cambridge University Press, Cambridge, p. 331-365.

Kay, R.F., Vizcaíno, S.F., Bargo, M.S., Perry, J.M.G., Prevosti, F.J., and Fernicola, J.C. 2008. Two new fossil vertebrate localities in the 
Santa Cruz Formation (late early Miocene, Argentina), 51 degrees South latitude. Journal of South American Earth Sciences 25: 187-195.

Krmpotic, C.M., Ciancio, M.R., Barbeito, C., and Carlini, A.A. 2009. Osteoderm morphology in recent and fossil Euphractinae Xenarthrans. Acta Zoologica 90: 339-351.

Linnaeus, C. 1758. Systema naturae per regna tria naturae, secundum classes, ordines, genera, species cum characteribus, differentis, synonymis, locis. Tomus I. Edito Decima, Reformata. Holmiae, Impensis Direct. Laurentii Salvii, 824 p.

Lydekker, R. 1894. Contribuciones al conocimiento de los vertebrados fósiles de la Argentina. Observaciones adicionales sobre los ungulados argentinos. Anales del Museo de La Plata 2: 1-248.

Marshall, L.G., Hoffstetter, R., and Pascual, R. 1983. Mammals and stratigraphy: Geochronology of the continental mammal-bearing Tertiary of South America. Paleovertebrata, Mémoire Extraordinaire 1-93.

Matheos, S.D., and Raigemborn, M.S. 2012. Sedimentology and paleoenvironment of the Santa Cruz Formation. In: S.F. Vizcaíno, R.F. Kay, and M.S. Bargo (Eds.), Early Miocene Paleobiology in Patagonia: High-Latitude Paleocommunities of the Santa Cruz Formation. Cambridge University Press, Cambridge, p. 59-82.

McKenna, M.C., and Bell, S.K. 1997. Classification of Mammals above the Species Level. Columbia University Press, New York, 640 p.

Mercerat, A. 1890. Sinopsis de la familia de los Astrapotheridae (Eoceno de Patagonia). Revista del Museo de La Plata 1: 241-255.

Mercerat, A. 1891. Notas sobre la paleontología de la República Argentina. II. Sinopsis de la familia de los Proxotodontidae conservados en el Museo de La Plata (Eoceno de Patagonia). Revista del Museo de La Plata 1: 381-444.

Mones, A. 1986. Palaeovertebrata Sudamericana. Catálogo sistemático de los vertebrados fósiles de América del Sur. Parte I. Lista Preliminar y Bibliografía. Courier Forschungsinstitut Senckenberg 82: 1-625.

Moreno, F.P. 1882. Patagonia. Resto de un antiguo continente sumergido. Anales de la Sociedad Científica Argentina 14: 97-131.

Moreno, F.P., and Mercerat, A. 1891. Notas sobre algunas especies de un género aberrante de los Dasypoda (eoceno de Patagonia) conservadas en el Museo de La Plata. Revista del Museo de La Plata 2: 57-63.

Pascual, R., Ortega Hinojosa, E.J., Gondar, D., and Tonni, E. 1965. Las edades del Cenozoico mamalífero de la Argentina, con especial atención a aquellas del territorio Bonaerense. Anales de la Comisión de Investigaciones Científicas 6: 165-193.

Parras, A.M., and Cuitiño, J.I. 2018.The stratigraphic and paleoenvironmental significance of the regressive Monte Observación Member, early Miocene of the Austral Basin, Patagonia. Latin American Journal of Sedimentology and Basin Analysis 25: 25-47.

Perkins, M.E., Fleagle, J.G., Heizler, M.T., Nash, B., Bown, T.M., Tauber, A.A., and Dozo, M.T. 2012. Tephrochronology of the Miocene Santa Cruz and Pinturas Formations, Argentina. In: S.F. Vizcaíno, R.F. Kay, and M.S. Bargo (Eds.), Early Miocene Paleobiology in Patagonia: High-Latitude Paleocommunities of the Santa Cruz Formation. Cambridge University Press, Cambridge, p. 2340.

Raigemborn, M.S., Matheos, S.D., Krapovickas, V., Vizcaíno, S.F., Bargo, M.S., Kay, R.F., Fernicola, J.C., and Zapata, L. 2015. Paleoenvironmental reconstruction of the coastal Monte León and Santa Cruz formations (Early Miocene) at Rincón del Buque, Southern Patagonia: A revisited locality. Journal of South American Earth Sciences 60: 31-55.
Sacomani, L.E., and Panza, J.L. 2011. Hojas Geológicas 5169-I y 5169-II, Puerto Coig y Puerto Santa Cruz, Provincia de Santa Cruz. Instituto de Geología y Recursos Minerales, Servicio Geológico Minero Argentino, Boletín 392: 1-133.

Scillato-Yané, G.J. 1980. Catálogo de los Dasypodidae fósiles (Mammalia, Edentata) de la República Argentina. $2^{\circ}$ Congreso Argentino de Paleontología y Bioestratigrafía y $1^{\circ}$ Congreso Latinoamericano de Paleontología (Buenos Aires), Actas 3: 7-36.

Scott, W.B. 1903. Mammalia of the Santa Cruz beds. Part I. Edentata. In: W.B. Scott (Ed.), Reports of the Princeton University Expeditions to Patagonia 1896-1899. Vol. 5, Paleontology 2, Princeton. Princeton University Press, New Jersey, p. 1-226.

Tauber, A.A. 1999. Los Vertebrados de la Formación Santa Cruz (Mioceno inferior-medio) en el extremo sureste de la Patagonia y su significado paleoecológico. Revista Española de Paleontología 14: 173-182.

Tauber, A.A., Palacios, M.E., Krapovickas, J., and Rodríguez, P. 2008. La Formación Santa Cruz (Mioceno temprano-medio) en la mitad occidental del Río Santa Cruz, Patagonia, Argentina. $17^{\circ}$ Congreso Geológico Argentino (Jujuy), Actas: 1500-1501.

Torcelli, A.J. 1935. Correspondencia científica. In: A.J. Torcelli (Ed.), Obras completas y correspondencia cientifica de Florentino Ameghino. Volumen 20. Taller de Impresiones Oficiales del Gobierno de la Provincia de Buenos Aires, La Plata, $621 \mathrm{p}$.

Trayler, R., Schmitz, M., Cuitiño, J.I., Kohn, M., Bargo, M.S., Kay, R., Strömberg, C., and Vizcaíno, S.F. 2019. An Improved Approach to Age-Modeling in Deep Time: Implications for the Santa Cruz Formation, Argentina. Geological Society of America Bulletin doi: https://doi.org/10.1130/B35203.1

Vizcaíno, S.F. 1994. Mecánica masticatoria de Stegotherium tessellatum Ameghino (Mammalia, Xenarthra) del Mioceno de Santa Cruz (Argentina). Algunos aspectos paleoecológicos relacionados. Ameghiniana 31: 283-290.

Vizcaíno, S.F. 2011. Cartas para Florentino desde la Patagonia. Crónica de la correspondencia édita entre los hermanos Ameghino (1887-1902). Publicación Especial de la Asociación Paleontológica Argentina 12: 51-67.

Vizcaíno, S.F., Bargo, M.S., Cuitiño, J.I., Pérez, M.E., Muñoz, N.A., Aramendía, I., Tomassini, R.L., and Kay, R.F. 2018. The outstanding Río Chalía (= Sehuén) outcrops of the Santa Cruz Formation (Early Miocene, Burdigalian) and its fossil vertebrate content. Publicación Electrónica de la Asociación Paleontológica Argentina 19: 85R.

Vizcaíno, S.F., Bargo M.S., and Fernicola, J.C. 2013. Expediciones paleontológicas durante los Siglos XIX y XX A la Formación Santa Cruz (Mioceno Inferior, Patagonia) y destino de los fósiles. $3^{\circ}$ Congreso Argentino de Historia de la Geología (Salta), Actas: 231-246.

Vizcaíno, S.F., Bargo, M.S., Kay, R.F., Fariña, R.A., Di Giacomo, M., Perry, J.M.G., Prevosti, F.J., Toledo, N., Cassini, G.H., and Fernicola, J.C. 2010. A baseline paleoecological study for the Santa Cruz Formation (late-early Miocene) at the Atlantic coast of Patagonia, Argentina. Palaeogeography, Palaeoclimatology, Palaeoecology 292: 507-519.

Vizcaíno, S.F., De luliis, G., Brinkman, P.D., Kay, R., and Brinkman, D.L. 2017. On an album of photographs recording fossils in the "Old Collections" of the Museo de La Plata and Ameghino's private collection at the beginning of the $\mathrm{XX}^{\text {th }}$ century. Publicación Electrónica de la Asociación Paleontológica Argentina 17: 14-23.

Vizcaíno, S.F., and Fariña, R.A. 1997. Diet and locomotion of the armadillo Peltephilus: a new view. Lethaia 30: 79-86.

Vizcaíno, S.F., Fernicola, J.C., and Bargo, M.S. 2012c. Paleobiology of 
Santacrucian glyptodonts and armadillos (Xenarthra, Cingulata). In: S.F. Vizcaíno, R.F. Kay, and M.S. Bargo (Eds.), Early Miocene Paleobiology in Patagonia: High-Latitude Paleocommunities of the Santa Cruz Formation, Cambridge University Press, Cambridge, p. $194-215$.

Vizcaíno, S.F., Kay, R.F., and Bargo, M.S. 2012a. Background for a paleoecological study of the Santa Cruz Formation (late Early Miocene) on the Atlantic Coast of Patagonia. In: S.F. Vizcaíno, R.F. Kay, and M.S. Bargo (Eds.), Early Miocene Paleobiology in Patagonia: High-Latitude Paleocommunities of the Santa Cruz Formation. Cambridge University Press, Cambridge, p. 1-22.

Vizcaíno, S.F., Kay, R.F., and Bargo, M.S. 2012b. Early Miocene Paleobiology in Patagonia: high-latitude paleocommunities of the Santa Cruz Formation. Cambridge University Press, Cambridge, 370 p.

Wetzel, R.M. 1985. Taxonomy and distribution of armadillos, Dasypodidae. The Evolution and Ecology of Armadillos, Sloths, and Vermilinguas. Smithsonian Institution Press, Washington, 2346 p.

Doi: 10.5710/PEAPA.14.10.2019.291

Recibido: 1 de abril 2019

Aceptado: 14 de octubre 2019

Appendix 1. List of the cingulates recorded in Barrancas Blancas (Estancia Aguada Grande and Estancia Santa Lucía), Segundas Barrancas Blancas (Estancia Cordón Alto and Estancia El Tordillo) and Yaten Huageno (Estancia El Refugio).

BARRANCAS BLANCAS (170 specimens) Peltephilus pumilus. MPM-PV 20818, osteoderm of the cephalic shield and carapace; MPM-PV 20816, MPM-PV 20819, MPM-PV 20821, and MPM-PV 20822, carapace osteoderms.

Peltephilus sp. MPM-PV 20820, fragment of cephalic shield osteoderm, MPM-PV 20817, fragment of cephalic shield osteoderm.

Stegotherium tessellatum. MPM-PV 20832, three osteoderms.

Prozaedyus proximus. MPM-PV 20844, small carapace fragment; MPM-PV 20845, small carapace fragment; MPM-PV 20848, osteoderms and small carapace fragment; MPM-PV 20833, MPM-PV 20834, MPM-PV 20835, MPM-PV 20836, MPM-PV 20837, MPMPV 20838, MPM-PV 20839, MPM-PV 20840, MPM-PV 20841; MPM-PV 20842, MPM-PV 20843, MPM-PV 20846, MPM-PV 20847, MPM-PV 20849, MPM-PV 20850, MPM-PV 20851, MPM-PV 20852, MPM-PV 20853, MPM-PV 20854, MPM-PV 20855, MPM-PV 20856, MPM-PV 20857, MPM-PV 20858, MPM-PV 20859, MPM-PV 20860, MPM-PV 20861, MPM-PV 20862, MPM-PV 20863, MPM-PV 20864, MPM-PV 20865, MPM-PV 20866, MPM-PV 20867, MPM-PV 20868, MPM-PV 20869, MPM-PV 20870, MPM-PV 20871, MPM-PV 20872, MPM-PV 20873, MPM-PV 20874, MPM-PV 20875, MPM-PV 20876, MPM-PV 20877, MPM-PV 20878, and MPM-PV 20879, carapace osteoderms.

Stenotatus patagonicus. MPM-PV 20932, MPM-PV 20933, MPM-PV 20934, MPM-PV 20935, MPM-PV 20936, MPM-PV 20937, MPM-
PV 20938, MPM-PV 20939, MPM-PV 20940, MPM-PV 20941, MPM-PV 20942, MPM-PV 20943, MPM-PV 20944, MPM-PV 20945, MPM-PV 20946, MPM-PV 20947, MPM-PV 20948, MPM-PV 20949, MPM-PV 20950, MPM-PV 20951, MPM-PV 20952, MPM-PV 20953, MPM-PV 20954, MPM-PV 20955, MPM-PV 20956, and MPM-PV 20957, carapace osteoderms.

Proeutatus oenophorus. MPM-PV 20981, osteoderms and postcranial elements; MPM-PV 21006, osteoderms and postcranial elements; MPM-PV 20982, MPM-PV 20983, MPM-PV 20984, MPM-PV 20985, MPM-PV 20986, MPM-PV 20987, MPM-PV 20988, MPM-PV 20989, MPM-PV 20990, MPM-PV 20991, MPM-PV 20992, MPM-PV 20993, MPM-PV 20994, MPM-PV 20995, MPM-PV 20996, MPM-PV 20997, MPM-PV 20998, MPM-PV 20999, MPM-PV 21000, MPM-PV 21001, MPM-PV 21002, MPM-PV 21003, MPM-PV 21004, MPM-PV 21005, MPM-PV 21007, MPM-PV 21008, MPM-PV 21009, MPM-PV 21010, MPM-PV 21011, MPM-PV 21012, MPM-PV 21013, MPM-PV 21014, MPM-PV 21015, MPM-PV 21016, MPM-PV 21017, MPM-PV 21018, MPM-PV 21019, MPM-PV 21020, MPM-PV 21021, and MPM-PV 21022, carapace osteoderms.

Cochlops muricatus. MPM-PV 21070, MPM-PV 21071, MPM-PV 21072, MPM-PV 21073, MPM-PV 21074, MPM-PV 21075, MPMPV 21076, MPM-PV 21077, MPM-PV 21078, MPM-PV 21079, MPM-PV 21080, and MPM-PV 21081, carapace osteoderms.

Eucinepeltus sp. MPM-PV 21084, cephalic shield osteoderm; MPMPV 21085, cephalic shield osteoderm.

Propalaehoplophoridae. MPM-PV 21111, osteoderms and postcranial elements; MPM-PV 21116, osteoderms and postcranium; MPMPV 21123, osteoderms and postcranial elements; MPM-PV 21096, MPM-PV 21097, MPM-PV 21098, MPM-PV 21099, MPM-PV 21100, MPM-PV 21101, MPM-PV 21102, MPM-PV 21103, MPM-PV 21104, MPM-PV 21105, MPM-PV 21106, MPM-PV 21107, MPM-PV 21108, MPM-PV 21109, MPM-PV 21110, MPM-PV 21112, MPM-PV 21113, MPM-PV 21114, MPM-PV 21115, MPM-PV 21117, MPM-PV 21118, MPM-PV 21119, MPM-PV 21120, MPM-PV 21121, MPM-PV 21122, MPM-PV 21124, MPM-PV 21125, MPM-PV 21126, MPM-PV 21127, MPM-PV 21128, and MPM-PV 21129, carapace osteoderms.

\section{SEGUNDAS BARRANCAS BLANCAS (186 specimens)}

Peltephilus pumilus. MPM-PV 20823, fragment of mandible and osteoderms; MPM-PV 20824, osteoderms and postcranial elements; MPM-PV 20828, MPM-PV 20830, MPM-PV 20825, MPM-PV 20831, and MPM-PV 20826, carapace osteoderms.

Peltephilus sp. MPM-PV 20827, cephalic shield osteoderm; MPM-PV 20829, fragment of mandible.

Prozaedyus proximus. MPM-PV 20882, osteoderms and postcranial elements; MPM-PV 20880, MPM-PV 20881, MPM-PV 20883, MPM-PV 20884, MPM-PV 20885, MPM-PV 20886, MPM-PV 20887, MPM-PV 20888, MPM-PV 20889, MPM-PV 20890, MPM-PV 20891, MPM-PV 20892, MPM-PV 20893, MPM-PV 20894, MPM-PV 20895, MPM-PV 20896, MPM-PV 20897, MPM-PV 20898, MPM-PV 20899, MPM-PV 20900, MPM-PV 20901, MPM-PV 20902, MPM-PV 20903, MPM-PV 20904, MPM-PV 20905, MPM-PV 20906, MPM-PV 20907, MPM-PV 20908, MPM-PV 20909, MPM-PV 20910, MPM-PV 20911, MPM-PV 20912, MPM-PV 20913, MPM-PV 20914, MPM-PV 20915, MPM-PV 20916, MPM-PV 20917, MPM-PV 20918, MPM-PV 20919, MPM-PV 20920, MPM-PV 20921, MPM-PV 20922, MPM-PV 20923, MPM-PV 20924, MPM-PV 20925, MPM-PV 20926, MPM-PV 20927, MPM-PV 20928, MPM-PV 20929, MPM-PV 20930, and MPM-PV 
21185, carapace osteoderms

Stenotatus patagonicus. MPM-PV 20958, MPM-PV 20959, MPM-PV 20960, MPM-PV 20961, MPM-PV 20962, MPM-PV 20963, MPMPV 20964, MPM-PV 20965, MPM-PV 20966, MPM-PV 20967, MPM-PV 20968, MPM-PV 20969, MPM-PV 20970, MPM-PV 20971, MPM-PV 20972, MPM-PV 20973, MPM-PV 20974, MPM-PV 20975, MPM-PV 20976, MPM-PV 20977, MPM-PV 20978, and MPM-PV 20979, carapace osteoderms.

Proeutatus oenophorus. MPM-PV 21037, osteoderms and postcranial elements; MPM-PV 21044, osteoderms and postcranial elements; MPM-PV 21053, fragment of mandible; MPM-PV 21049, fragment of maxilar; MPM-PV 21023, MPM-PV 21024, MPM-PV 21025, MPMPV 21026, MPM-PV 21027, MPM-PV 21028, MPM-PV 21029, MPM-PV 21030, MPM-PV 21031, MPM-PV 21032, MPM-PV 21033, MPM-PV 21034, MPM-PV 21035, MPM-PV 21036, MPM-PV 21038, MPM-PV 21039, MPM-PV 21040, MPM-PV 21041, MPM-PV 21042, MPM-PV 21043, MPM-PV 21045, MPM-PV 21046, MPM-PV 21047, MPM-PV 21048, MPM-PV 21050, MPM-PV 21051, MPM-PV 21052, MPM-PV 21054, MPM-PV 21055, MPM-PV 21056, MPM-PV 21057, MPM-PV 21058, MPM-PV 21059, MPM-PV 21060, MPM-PV 21061, MPM-PV 21062, MPM-PV 21063, MPM-PV 21064, and MPM-PV 21065, carapace osteoderms.

Eucinepeltus sp. MPM-PV 21086, cephalic shield osteoderm; MPMPV 21087, MPM-PV 21088, MPM-PV 21089, MPM-PV 21090, MPM-PV 21091, MPM-PV 21092, MPM-PV 21093, MPM-PV 21094, and MPM-PV 21095, carapace osteoderms, and a cephalic shield osteoderm; and MPM-PV 21169, carapace osteoderms.
Propalaehoplophoridae. MPM-PV 21139, fragment of mandible; MPM-PV 21140, osteoderms, fragment of skull, and postcranial elements; MPM-PV 21165, osteoderms and a molariform; MPM-PV 21130, MPM-PV 21131, MPM-PV 21132, MPM-PV 21133, MPMPV 21134, MPM-PV 21135, MPM-PV 21136, MPM-PV 21137, MPM-PV 21138, MPM-PV 21141, MPM-PV 21142, MPM-PV 21143, MPM-PV 21144, MPM-PV 21145, MPM-PV 21146, MPM-PV 21147, MPM-PV 21148, MPM-PV 21149, MPM-PV 21150, MPM-PV 21151, MPM-PV 21152, MPM-PV 21153, MPM-PV 21154, MPM-PV 21155, MPM-PV 21156, MPM-PV 21157, MPM-PV 21158, MPM-PV 21159, MPM-PV 21160, MPM-PV 21161, MPM-PV 21162, MPM-PV 21163, MPM-PV 21164, MPM-PV 21166, MPM-PV 21167, MPM-PV 21168, MPM-PV 21170, MPM-PV 21171, MPM-PV 21172, MPM-PV 21173,; MPM-PV 21174, MPM-PV 21175, MPM-PV 21176, MPMPV 21177, MPM-PV 21178, and MPM-PV 21179, carapace osteoderms.

YATEN HUAGENO (12 specimens)

Prozaedyus proximus. MPM-PV 20931, carapace osteoderms. Stenotatus patagonicus. MPM-PV 20980, carapace osteoderms. Proeutatus oenophorus. MPM-PV 21066, MPM-PV 21067, MPM-PV 21068, and MPM-PV 21069, carapace osteoderm.

Cochlops muricatus. MPM-PV 21082, and MPM-PV 21083, carapace osteoderms.

Propalaehoplophoridae. MPM-PV 21181, ungual phalanx; MPM-PV 21183, osteoderms and postcraneal elements; MPM-PV 21182, and MPM-PV 21180, carapace osteoderms. 